\section{DESCRIPTION OF FAVITES MONTICULARIS SP. NOV. (FAVIIDAE) OFF NORTH ANDAMAN ISLANDS, INDIA}

\section{Tamal Mondal $^{1}$, C. Raghunathan ${ }^{2} \&$ K. Venkataraman ${ }^{3}$}

1,2 Zoological Survey of India, National Coral Reef Research Institute, Port Blair, Andaman and Nicobar Islands 744102, India

${ }^{3}$ Zoological Survey of India, Prani Vigyan Bhawan, M- Block, New Alipore, Kolkata, West Bengal 700053, India

${ }^{1}$ t_genetics@yahoo.com (corresponding author), ${ }^{2}$ raghuksc@rediffmail.com, ${ }^{3}$ venkyzsi56@gmail.com

Scleractinian corals are described under 18 families. Among these, Faviidae is denoted as the second largest family having 126 species of corals belonging to 24 genera (Veron 2000). Veron (1986) described the characteristics as well as differentiation among the genera such as Favia, Barabattoia, Favites, and Montastrea. Veron (2000) summarized a total of 14 species of corals under the genus Favites among 16 extant species. The described species under the genus Favites are flat, rounded, massive, encrusting with irregular compact organization. Corallites are monocentric and cerioid with fused structural form with the presence of common wall which is acute. Leafy walls are composed of 6-8 $\mathrm{mm}$ deep fossa. Calices are variable in structure such as oval, polygonal and angular with a series. Several marginally spiny septa are developed from the fossa with prominent dentations. Colonies are usually brown to green but the peristome region can be seen with contrasting colour. The Andaman \& Nicobar Islands represent diverse scleractinian corals of the genus Favites with new records of spinosa, paraflexuosa and micropentagona (Mondal et al. 2010a,b). These islands also represent a high diversity of scleractinian corals at North and Middle Andaman \& Ritchie's Archipelago (Mondal et al. 2011, 2012a). This paper deals with the taxonomic description of a species which bears a unique compelling character to be described as new to science.

Material and Methods: The holotype coral specimen was sampled from off Shibpur, Diglipur, North Andaman by self contained

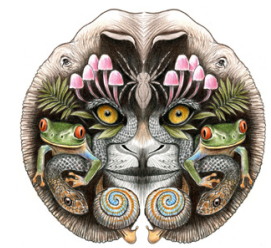

ISSN

Online 0974-7907 Print 0974-7893

\section{OPEN ACCESS} underwater breathing apparatus (SCUBA) diving. Collected material was kept in freshwater for six days to remove the mucous substances and air dried for examination. Morphological measurements were made with Vernier Caliper (Aerospace 074 15376). Characteristic features of the specimen were examined under the Digital Stereozoom Microscope, Model Leica M 205 A. Taxonomic characters of the specimen were studied in consultation with Veron et al. (1977) and Veron (2000).

Order: Scleractinia Bourne, 1900

Suborder: Faviina Vaughan and Wells, 1943

Family: Faviidae Gregory, 1900

Genus Favites Link, 1807

\section{Favites monticularis sp. nov.}

urn:Isid:zoobank.org:act:51885921-4955-4FB4-BEOB-113D1D4FCC12

Material Examined: Holotype: ZSI/ANRC-7410, 03.iii.2012, a small terminal portion of the observed colony (Image 1 ) was sampled at a depth of $14 \mathrm{~m}$ in a reef area off Shibpur $\left(13^{\circ} 14.439^{\prime} \mathrm{N} \& 92^{\circ} 02.971^{\prime} \mathrm{E}\right)$, located at Diglipur, North Andaman. The area of the observed colony was about $1 \mathrm{~m}^{2}$.

The measurement of the sample is as follows: length$3.5 \mathrm{~cm}$, width $-2.1 \mathrm{~cm}$ and height $-1.5 \mathrm{~cm}$. Holotype is deposited in the National Zoological Collections of Zoological Survey of India, Port Blair. Five colonies were

DOI: http://dx.doi.org/10.11609/JoTT.o3224.4510-3 | ZooBank: urn:Isid:zoobank.org:pub:7DB0F983-8CAE-4674-8019-6E3A1A4B616B

Manuscript details: Ms \# 03224 | Received 20 December 2012 | Final received 06 April 2013 | Finally accepted 17 June 2013

Citation: Mondal, T., C. Raghunathan \& K. Venkataraman (2013). Description of Favites monticularis sp. nov. (Faviidae) off North Andaman Islands, India. Journal of Threatened Taxa 5(10): 4510-4513; http://dx.doi.org/10.11609/JoTT.o3224.4510-3

Copyright: (c) Mondal et al. 2013. Creative Commons Attribution 3.0 Unported License. JoTT allows unrestricted use of this article in any medium, reproduction and distribution by providing adequate credit to the authors and the source of publication.

Funding: Ministry of Environment and Forests, Government of India.

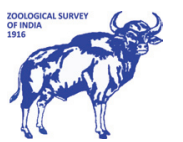

Acknowledgements: Authors are grateful to the Ministry of Environment and Forests, Government of India for financial support and facilities provided. 

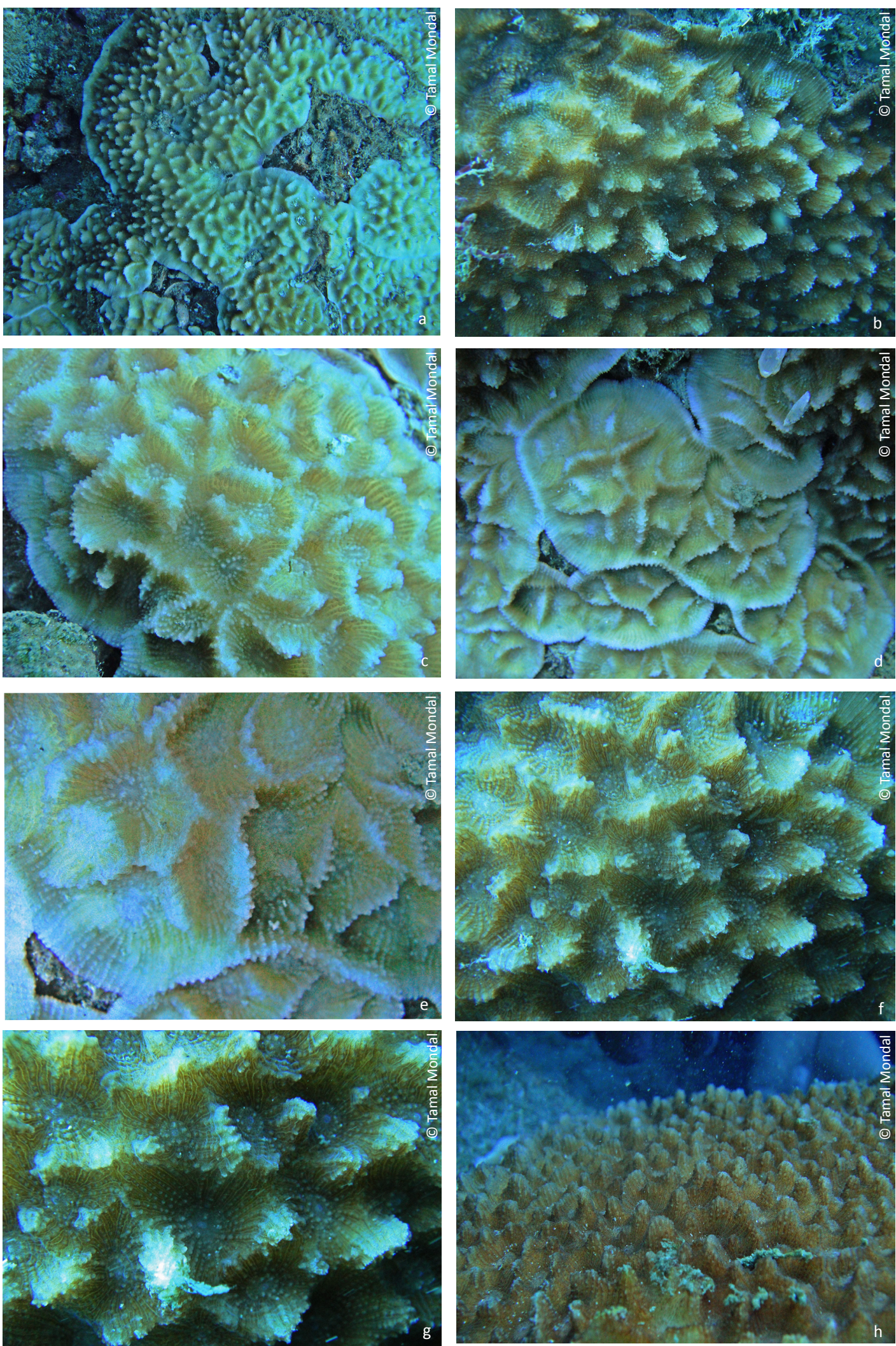

Image 1. a-h - Underwater live colonies with monticule shaped structure.

a - Encrusting holotype colony; b - Holotype colony with monticule shaped structure; c - Holotype colony showing corallites and monticule shaped structure at the septal wall; $d$ - Colony of paratype; e - Paratype colony with terminal corallites; $f$ - Paratype colony with monticule shaped structure; $\mathrm{g}$ - Close-up image of corallites and monticule shape character; $\mathrm{h}$ - Side view of colony to distinguish monticule shaped character separately 

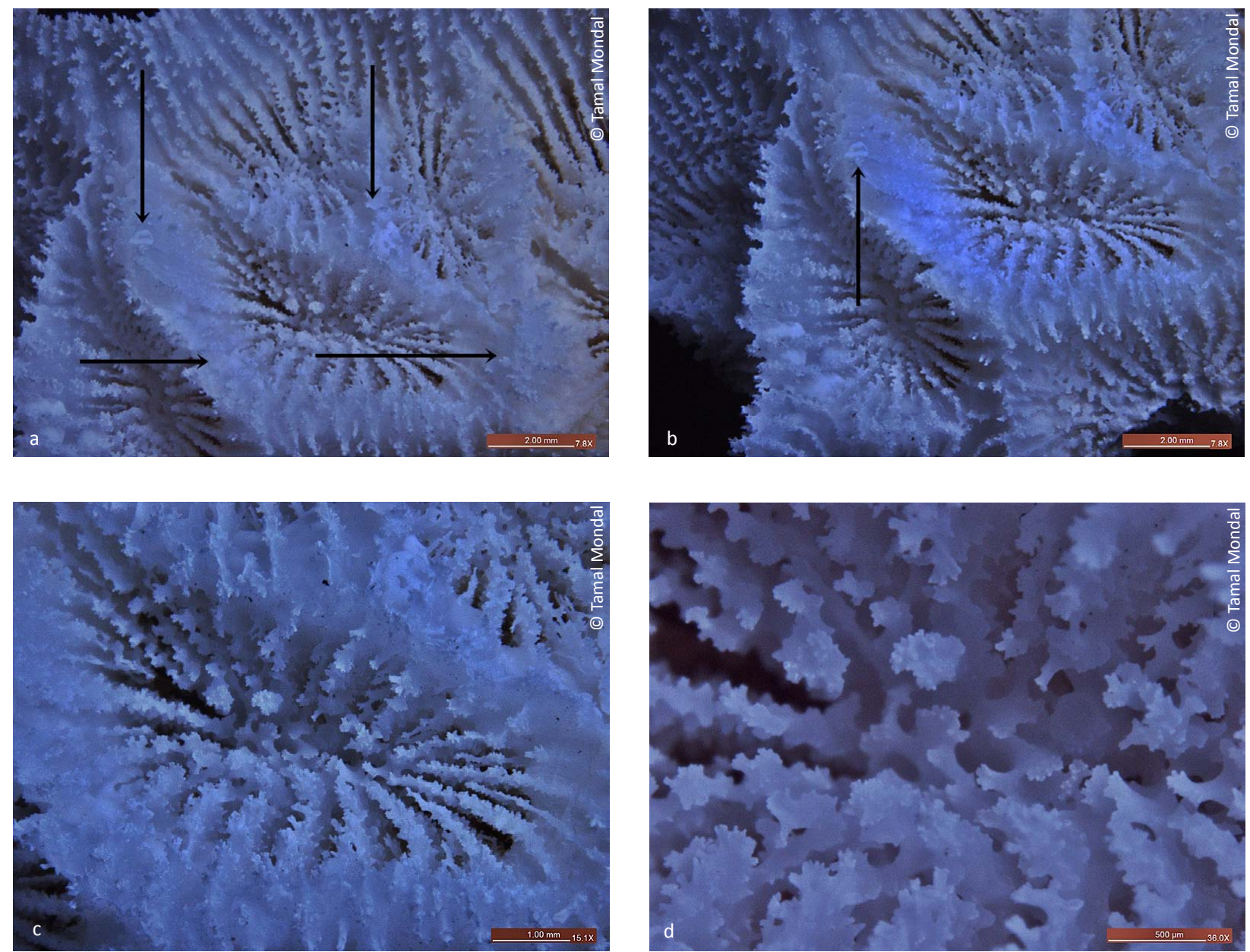

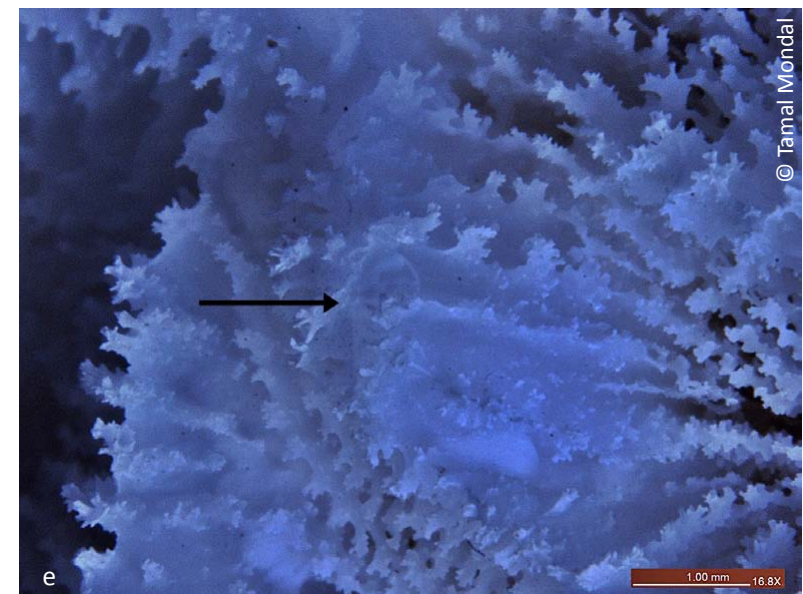

Image 2. Different key characters of Favites monticularis sp. nov. a - Corallites (inner portion); b - Corallites (terminal portion); c - Septal arrangement with dentition; $\mathbf{d}$ - Paliform lobes and coenosteum; e - Monticules shaped structure. observed from the same study area (Image 2).

Diagnostic characters: The colonies of Favites monticolaris sp. nov. are encrusting, massive. Corallites are cerioid. The diameter of the corallites is 6-10 $\mathrm{mm}$. Two septal cycles can be distinguished. Lengths of the septa are variable. The first order septa reach the columella while the second order may or may not. Paliform lobes are well developed, echinose in structure. Septal dentition is also well formed in echinose pattern. Columella is poorly developed and loose. Septa are variable and exert over the theca forming conical-shaped monticule structures. These are regular and variable in length of 2-3 $\mathrm{mm}$ according to corallites structure. Due to the presence of monticules, the colonies appear as serially arranged upwards and downwards structures (Image 2).

Closely related species: Favites pentagona is a very closely related species. This species does not have a monticule like structure. Favites monticolaris sp. nov. is also closely related to Hydnophora microconos in lateral view.

Colour: Colonies are green to brown in colour. Centre of the corallites or columella is pale and the monticules 
Table 1. Comparison of key characters of different species under genus Favites

\begin{tabular}{|c|c|c|}
\hline Sno & Species name & Specific characters \\
\hline 1. & Favites stylifera & Corallites very small (<6mm in diameter), corallites irregular in shape. \\
\hline 2. & Favites micropentagona & Corallites very small (<6mm in diameter), corallites uniform in shape. \\
\hline 3. & Favites pentagona & Corallites small (6-10 mm in diameter), corallites angular, paliform lobes well developed. \\
\hline 4. & Favites spinosa & Corallites small (6-10 mm in diameter), corallites angular, paliform lobes weakly developed or absent, septa very exsert. \\
\hline 5. & Favites acuticollis & Corallites small (6-10 mm in diameter), corallites angular, paliform lobes weakly developed or absent, septa not exsert. \\
\hline 6. & Favites bestae & Corallites small (6-10 mm in diameter), corallites rounded, paliform lobes well developed. \\
\hline 7. & Favites chinensis & Corallites small (6-10 $\mathrm{mm}$ in diameter), corallites rounded, paliform lobes absent. \\
\hline 8. & Favites halicora & Corallites middle-sized (10-14 mm in diameter), colony surface hillocky. \\
\hline 9. & Favites russelli & Corallites middle-sized (10-14 mm in diameter), colony not hillocky, septa irregularly exsert. \\
\hline 10. & Favites abdita & Corallites middle-sized (10-14 mm in diameter), colony not hillocky, septa not irregular, corallites angular. \\
\hline 11. & Favites complanata & Corallites middle-sized (10-14 mm in diameter), colony not hillocky, septa not irregular, corallites rounded. \\
\hline 12. & Favites vasta & Corallites large ( $>14 \mathrm{~mm}$ in diameter), corallites rounded. \\
\hline 13. & Favites flexuosa & Corallites large ( $>14 \mathrm{~mm}$ in diameter), corallites angular, septal teeth conspicuous. \\
\hline 14. & Favites paraflexuosa & Corallites large (>14mm in diameter), corallites angular, septal teeth not conspicuous. \\
\hline 15. & Favites monticularis sp. nov. & $\begin{array}{l}\text { Corallites small (6-10 mm in diameter), corallite angular, paliform lobes well developed, presence of monticule shaped } \\
\text { structure }\end{array}$ \\
\hline
\end{tabular}

are whitish in colour.

Etymology: Monticularis is based on the word monticule which means small hill or mound, as the species bears small hill (monticule) shaped structure on the septal wall, which distinguishes this species from other species of the genus Favites.

The presently described species has been compared with other 14 species of Favites reported from worldwide with their key taxonomical features (Table 1).

Discussion: The Andaman and Nicobar Islands harbor a great deal of scleractinian corals which makes this area one of the highly diversified reef areas in the Indo-Pacific region. Favites monticularis sp. nov. is described as a new scleractinian coral species from the Andaman and Nicobar Islands. Although this species shows a close resemblance to Favites pentagona, in morphological characters - it also shows a distinct difference with the presence of monticule. This character makes this species unique. Apart from the described holotype of Favites monticularis reported from off Shibpur, five more colonies of the presently described species were observed from the same study area and subsequently three colonies at Neil Island $\left(11^{\circ} 50.857^{\prime} \mathrm{N}\right.$ \& $930^{\circ} 1.140^{\prime} \mathrm{E}$ ) and two colonies at Havelock Island $\left(11^{\circ} 53.274^{\prime} \mathrm{N} \& 930^{\circ} 1.439^{\prime} \mathrm{E}\right)$ during underwater status survey of scleractinian corals. Mondal et al. (2012b) reported a total of 88 species of faviids with 13 species of Favites from these groups of islands. This new species under the genus Favites is not only an addition to scleractinian order but also new to science.

\section{REFERENCES}

Link, H.T. (1807). Beischreibung der Naturalien Sammlungen der Universitat zu Rostock. 3: 161-165.

Mondal, T., C. Raghunathan \& K. Venkataraman (2012a). Scleractinian Diversity of Ritchie's Archipelago, Andaman \& Nicobar Island. Global Journal of Science Frontier Research 12(4): 53-64.

Mondal, T., C. Raghunathan \& K. Venkataraman (2012b). An account of Faviid Corals of Andaman \& Nicobar Islands. Research Journal of Science and Technology 4(2): 62-66.

Mondal, T., C. Raghunathan \& K. Venkataraman (2011). Diversity of Scleractinian Corals in Middle and North Andaman Archipelago. World Journal of Zoology 6(4): 407-419.

Mondal, T., C. Raghunathan, C. Sivaperuman \& Ramakrishna (2010a). Identification of Seven Scleractinian Corals from Andaman \& Nicobar Island as New Record to Indian Water. Proceedings of Zoological Society 63(1): 61-66.

Mondal, T., C. Raghunathan \& Ramakrishna (2010b). New Record of Thirteen Scleractinian Corals in Indian Waters from Middle and North Andaman. Biosystematica 4(2): 75-89.

Vaughan, T.W. \& J.W. Wells (1943). Revisions of the sub-order, family and genera of the Scleractinia. Geological Society American Special Paper 44: 1-363.

Veron, J.E.N. (2000). Corals of the World - Volumes 1 \& 3. Australian Institute of Marine Science, Townsville, 463pp \& 490pp.

Veron, J.E.N. (1986). Corals of Australia and the Indo-Pacific. Australian Institute of Marine Science and the University of Hawaii Press, Honolulu, 644pp.

Veron, J.E.N., M. Pichon \& M. Wijsman-Best (1977). Scleractinia of eastern Australia, II. Families Faviidae, Trachyphylliidae 3. Australian Institute of Marine Science, Monograph Series, 1-233pp. 